\title{
Life writing as a source for local population history
}

\author{
Colin G Pooley \\ c.pooley@1ancaster.ac.uk
}

\author{
Marilyn E Pooley \\ m.pooley@1ancaster.ac.uk
}

\section{Biographical notes:}

Colin Pooley is Emeritus Professor of Social and Historical Geography in the Environment Centre, Lancaster University, UK. His research focuses on the social geography of Britain and continental Europe since circa 1800, with recent projects focused on residential migration, travel to work and other aspects of everyday mobility.

Marilyn Pooley is an Historical Geographer. She was formerly a Teaching Associate in the Environment Centre at Lancaster University, UK, and in retirement is researching (with Colin Pooley) everyday mobility in nineteenth and twentieth century Britain using life writing. 


\title{
Life writing as a source for local population history
}

\begin{abstract}
Diaries and other forms of life writing can add significantly to the study of local populations and societies, especially when used in conjunction with more conventional aggregate sources. All the key demographic events have important personal and emotional resonances that can never be revealed by statistical analysis of births, marriages or deaths. Personal accounts can add meaning to population history and demonstrate the familial and community impacts of key life events. In this paper we examine the strengths and weaknesses of different types of life writing, and then focus on the ways in which personal diaries may provide insights into the meanings and implications of life events such as courtship, marriage, childbirth, illness and death. Examples are drawn from a range of diaries written in Britain between the 1840s and 1950s.
\end{abstract}

\section{Introduction}

Most demographic information is presented in the form of aggregate statistics. These may be constructed from individual level data on, for example, marriages, baptisms, births, burials or deaths, but analysis is most often carried out with large aggregated datasets that refer to specific spatial units such as wards, parishes or counties. ${ }^{1}$ There are good reasons for this. Such data

\footnotetext{
${ }^{1}$. As demonstrated in many papers published in this journal. Two recent examples are: E. Garrett and A. Reid, 'Composing a national picture from local scenes: new and future insights into the fertility transition', Local Population Studies, 100 (2018), pp. 60-76; R. Leadbetter, 'Smallpox in Oxfordshire, 1700-99, and the implications of family transmission routes', Local Population Studies, 98 (2017), pp. 12-29.
} 
enable the smoothing of fluctuations over time and of variability due to unusual events or data deficiencies, and they also allow reliable comparisons to be made over time and between locations. Aggregated data can also be easily mapped within whatever spatial units are appropriate. However, despite the ubiquity and utility of such data analysis and presentation, much is lost in the process of aggregation. The very variability that is smoothed in the process of aggregation may have real significance at the local level, and the events themselves can too easily become simply numbers rather than personal events that have meanings and emotions attached to them. Marriage, childbirth and death are all major life events that fundamentally affect people's lives and the communities in which they live. Consequently, it is important to consider the personal and emotional impacts of demographic events and to assess their impact on later life trajectories. Various genres of life writing can be used in conjunction with more conventional demographic data to examine some of the personal perspectives that are otherwise neglected.

Life writing can take a number of different forms. The three most commonly available sources are diaries, autobiographies and letters, but other personal papers may also be relevant and some creative writing that draws heavily on personal life experiences can be considered to be part of the genre of life writing. There are fundamental differences (briefly explained below) between each of these sources. Autobiographies are the life-writing form that has been used most frequently in historical research. ${ }^{2}$ These are normally written late in life and create a narrative over the life course. They are mainly written by men and, inevitably, tend to gloss over some aspects and foreground others. They may also be written with a view to the justification of

\footnotetext{
${ }^{2}$. For example: A. Vickery, The Gentleman's Daughter: Women's Lives in Georgian England (New Haven, Conn., 1998; J. Humphries, Childhood and Child Labour in the British Industrial Revolution (Cambridge, 2010); L. Delap, Knowing Their Place: Domestic Service in Twentieth-century Britain (Oxford, 2011); E. Griffin, Liberty's Dawn: A People's History of the Industrial Revolution (New Haven, Conn., 2013).
} 
certain past actions, or to pass on information to the next generation. They often focus on unusual or distinctive events and omit the mundane, yet most people's lives do consist of relatively mundane activities, some of which will stem from key demographic events. ${ }^{3}$ Letters may be revealing, but survive much more rarely and are likely to be written sporadically in response to particular activities or events. It is rare to find collections of two-way correspondence: most consist either of letters sent, as recorded in a letter book, or of those received, ${ }^{4}$ and as a result much context is missed. Many writers of fiction such as Charles Dickens or George Gissing drew heavily on personal experience in some of their novels, but they also had licence to dramatize the lives of their characters for the sake of a plot. Such evidence must be treated with caution by the historian. ${ }^{5}$ Personal diaries are probably the most useful for local population studies and will form the main focus of this paper. In theory they do

${ }^{3}$. D. Vincent, Bread, Knowledge and Freedom: A Study of Nineteenth-Century Working Class Autobiography (London, 1981); S. Sherman, 'Diary and autobiography', in J. Richetti (ed), The Cambridge History of English Literature, 1660-1780 (Cambridge, 2005), pp. 623-48; M. Hewitt, 'Diary, autobiography and the practice of life history', in D. Amigoni (ed), Life Writing and Victorian Culture (London, 2006) pp. 21-39.

${ }^{4}$. For instance see: P. Laxton, 'Fighting for Public Health: Dr Duncan and his adversaries, 1847-1863,' in S. Sheard and H. Power (eds), Body and City: Histories of Urban Public Health (Abingdon, 2000) pp. 59-88; M. Jolly and L. Stanley, 'Letters as / not a genre', Life Writing, 2 (2005), pp. 91-118.

${ }^{5}$. For example: J. Spiers, (ed), Gissing and the City: Cultural Crisis and the Making of Books in LateVictorian England (Palgrave Macmillan, 2006); R. Dennis, 'The place of Bloomsbury in the novels of George Gissing', Opticon, 1826 (2009); L. Pearce, Drivetime: Literary Excursions in Automotive Consciousness (Edinburgh, 2016). 
describe day by day events, potentially providing a record of both the unexpected and the mundane.

\section{Diaries: strengths and limitations}

Personal diaries have many advantages. They are often written up on a daily basis (or at least very frequently), thus giving an immediate reaction to events. They have the capacity to record repetitive, mundane activities, such as travel to work or for shopping, as well as more unusual and disruptive demographic events such as childbirth or a family death. They can provide wider context to the circumstances in which such events occurred and may provide details that are never recorded elsewhere. For local population studies they are perhaps most valuable for studying everyday mobility which is rarely recorded in any form elsewhere, but they can also provide new insights into rarer demographic events that occurred within the time frame of the diary. However, it is also important to be aware of the limitations of, and problems with, the use of diaries for historical research. At a practical level they are often hard to locate in record offices or private collections, and may be written in handwriting that is difficult to read. Working with diaries can be very time-consuming. Like many archival sources any diary collection is a small sample of an unknown total population and they cannot claim any representativeness beyond the individual diarist. Diaries were obviously written by those with a sufficient level of literacy and leisure time to keep a diary and young female writers tend to dominate diary collections. Fulltime employment for men and motherhood for women usually restricted diary writing. Many diaries that were written have not survived: either they were destroyed by their authors in later life or by relatives after the diarist's death, or they were simply lost in multiple house moves. There is also no way of knowing what was omitted from a diary. Inevitably there is a tendency for diarists to record unusual events, though most also note some mundane activities, but the degree of detail included varies enormously. For instance, some diarists do no more than provide a simple factual account, while others record both factual details and the feelings and emotions 
that an event generated. Diaries that do contain very personal information can also raise ethical questions about what should be used, especially if there is a clear indication that the diary was meant to be private. Again, young women were much more likely to do this, although the degree to which this was the case varied greatly. Diaries are thus not without their difficulties of use, and conclusions drawn from them will inevitably be affected by the range of diaries used by a researcher, but we argue that, used carefully, they may provide valuable additional information for the local population historian. ${ }^{6}$

Whereas many autobiographies have been published in a variety of forms, ${ }^{7}$ and are thus more easily located and used, most diaries remain unpublished and widely scattered. Published diaries and memoirs tend to be those written by elites who were in the public eye at some time of their

\footnotetext{
${ }^{6}$. For further discussion of the strengths and weaknesses of diaries, see for example: A.
} Ponsonby, English Diaries: A Review of English Diaries From the Sixteenth to the Twentieth Century, With an Introduction on Diary Writing (London, 1923); R. Fothergill, Private Chronicles: A Study of English Diaries (London, 1974); F. Nussbaum, 'Toward conceptualizing diary,' in F. Naussbaum and J. Olney (eds), Studies in Autobiography (Oxford, 1988) pp. 128-140; R. Hogan, 'Engendered autobiographies: the diary as a feminine form', Prose Studies, 14 (1991), pp. 95-107; J. Hunter, J. 'Inscribing the self in the heart of the family: Diaries and girlhood in late-Victorian America', American Quarterly, 44 (1992), pp. 51-81; Hewitt, 'Diary, Autobiography and the Practice of Life History'; R. Steinitz, Time, Space, and Gender in the Nineteenth-Century British Diary (New York, 2011).

${ }^{7}$. For instance: J. Burnett, Useful Toil: Autobiographies of Working People from the 1820s to the 1920s (London: 1974); J. Burnett, Destiny Obscure: Autobiographies of Childhood, Education and Family from the 1820s to the 1920s (London, 1982); Vincent, Bread, Knowledge and Freedom; J. Burnett, D. Vincent and D. Mayall, The autobiography of the working class: an annotated critical bibliography (Brighton, 1984). 
life and may have been carefully constructed with a view to later publication. ${ }^{8}$ This may also be true of the diary collection held by Mass Observation as the writers were aware that they were producing material that would be viewed by others. ${ }^{9}$ Unpublished diaries written by people with no public profile and no view to later publication are likely to be much more useful to the local population historian. While some personal diaries have been transcribed and published by local record societies, ${ }^{10}$ and are therefore reasonably readily available, many other diaries remain unpublished. Most local archives are likely to contain some diaries among deposits of personal papers, and there are a small number of larger diary collections, but many such sources remain in private hands. Two important diary collections that are worth special mention are the Edward Hall collection in the Wigan archives, ${ }^{11}$ and the diaries deposited at the Bishopsgate Institute, London, ${ }^{12}$ through the 'Great Diary Project'. ${ }^{13}$ The Edward Hall collection consists of over 200 diaries and related material, and the Bishopsgate Institute archive currently has some 440 separate items catalogued, but with more being added as they become available. Both collections have on-line catalogues in which local historians may find something relevant to their studies.

${ }^{8}$. Examples include: V. Brittain, Testament of Youth: an autobiographical study of the years 1900-1925 (New York, 1933); R. Crossman, The Diaries of a Cabinet Minister (London, 197577); T. Benn, The Benn Diaries: 1940-1990 (London, 1996).

9 . Mass Observation: http://www.massobs.org.uk/mass-observation-1937-1950s.

${ }^{10}$. For instance the diaries of John Carrington published by the Hertfordshire Record Society (volume XXV1, 2015).

${ }^{11}$. Wigan Archives: https://www.wigan.gov.uk/Resident/Museums-archives/WiganArchives/Collections/People-and-families/Edward-Hall-diary-collection.aspx (accessed 24 April 2019).

${ }^{12}$. Bishopsgate Institute: https://www.bishopsgate.org.uk/Library (accessed 24 April 2019).

${ }^{13}$. The Great Diary Project: https://www.thegreatdiaryproject.co.uk/(accessed 24 April 2019). 
There are, of course, many other qualitative sources that can provide data relevant to the local population studies. These include oral interviews, court records and newspaper articles amongst other documents, but few provide the immediate and largely unconstructed narrative of most personal diaries. ${ }^{14}$ From the perspective of the historical demographer diaries are most valuable for the study of events that occurred frequently, such as everyday mobility, but they may also record a full range of other demographic activities and events including residential migration, childbirth, illness and a family death, courtship and marriage. We have examined some 50 diaries written in Britain from the early-nineteenth century to the mid-twentieth century. The examples given below draw on a representative selection of this life writing. ${ }^{15}$

\section{Mortality}

Even in the past when mortality rates were high by twenty-first century standards, a family death was a relatively rare event and thus may not occur during the period of a diary. In addition, the

${ }^{14}$. For an example of how court records may be used to study everyday mobility see: C. Pooley, 'On the street in nineteenth-century London', Urban History (in press 2019)

${ }^{15}$. For further information on our use of diaries to study (mainly) mobility see: C. Pooley and M. Pooley, "Mrs Harvey came home from Norwich ... her pocket picked at the station and all her money stolen": using life writing to recover the experience of travel in the past', Journal of Migration History, 1 (2015), pp. 54-74; C. Pooley, 'Cities, spaces and movement: everyday experiences of urban travel in England c1840-1940', Urban History, 44 (2017), pp. 91-109; C. Pooley, 'Travelling through the city: using life writing to explore individual experiences of urban travel c1840-1940', Mobilities, 12 (2017), pp. 598-609; C. Pooley and M. Pooley, “'We're going to move ... I can't rush backwards and forwards, I'll go mad - I am sure of it." Representations of speed and haste in English life writing 1846-1958', in G. Mackintosh, P. Dennis and R. Holdsworth (eds), Architectures of Hurry - Mobilities, Cities and Modernity (London, 2018) pp. 194208. 
disruption and trauma caused by illness and death may cause a temporary hiatus in diary writing, either because of a lack of time or due to the emotions generated being too painful to record. However, several of the diaries we have studied do record a family death and its impact. One of the most poignant is the death of three year old Freddie Lee as recorded by his older sister Elizabeth in June 1887 when she was 20 years old and living at home in Prenton near Birkenhead (Cheshire). Three brief extracts from her diary demonstrate clearly the impact that this event had on the whole family:

The doctor gave poor darling Freddie up this morning, as he has got 'water on the brain'. The poor little thing is suffering dreadfully. I can't believe he is going to die, he is quite blind and can't speak. ${ }^{16}$

He passed away so peacefully without a sigh. It was just 2 O'clock. I felt awful when I knew he was dead. Pa had to go straight of [sic] to Upton in the trap to register him. Tod and Percy went with him. I helped Mrs. Randalls and Ma to lay dear Freddie out. He is just like wax and looks so beautiful. ${ }^{17}$

Freddie was buried today at 'Flaybrick Hill Cemetery'. Uncle George and John Carless carried the coffin. and Ma and Pa. Toddy and Percy all went to the funeral. I did so want to go, but could'nt very well, as I had'nt a black dress. I felt awful after he had gone. ${ }^{18}$

Other diaries may record a death more briefly and with less obvious emotion but nonetheless they can still convey a clear sense of loss and, in the case of the death of an adult who provided

\footnotetext{
${ }^{16}$. Diary of Elizabeth Lee, Wednesday June $1^{\text {st }} 1887$. Published in: C. Pooley, S. Pooley and R. Lawton (eds), Growing up on Merseyside in the late-nineteenth century: the diary of Elizabeth Lee (Liverpool, 2010).

${ }^{17}$. Diary of Elizabeth Lee, Saturday June $4^{\text {th }} 1887$. Pooley et al., Growing up on Merseyside.

${ }^{18}$. Diary of Elizabeth Lee, Monday June $6^{\text {th }} 1887$. Pooley et al., Growing up on Merseyside.
} 
for the family, of the disruption and difficulties that the death of a parent or spouse could cause. One such example is recorded in the diary of Mrs Blake whose husband John died at home in December 1903. The diary entry is brief but the pain is clear: 'Poor John nearing the end of this life - coma set in early this evening after which he talked unintelligibly until he passed away. $\mathrm{Mr}$ Weeks there for about 2 hrs. No one could understand a word my poor husband was saying. The boys there with him. ${ }^{, 19}$

One final example shows both the immediate and longer-term impact of a family death on the life of a young diarist. Annie Rudoff was aged 18 and living at home in London with her parents and younger siblings when her mother died following an operation. Annie was clearly heartbroken at the time, but this death also had a more lasting effect on her life: she was expected (as the eldest daughter at home) to take on all the duties of her mother for housework and care of her siblings and, because her family was Jewish, she was also required to observe a year of mourning in which she was not allowed to do anything frivolous for pleasure such as going to dances and the theatre. Her life was fundamentally changed, as shown by two brief extracts from many entries:

Oh little book, how am I going to live - how can I tell you my feelings - how heartbroken I am ... Oh Mother you took my heart with you - why did you leave us my mother - I know you did not want to leave us ... I go about heart-broken ... ${ }^{20}$

${ }^{19}$. Diary of Mrs Blake, Thursday December $17^{\text {th }}$ 1903. Bishopsgate Institute Archive, London, GDP/100. Few personal details are available for this diarist who lived in London.

${ }^{20}$. Diary of Annie Rudoff, Friday May $11^{\text {th }}$ 1923. Bishopsgate Institute Archive, London, GDP/31. 
I used to go out in the week ends and enjoy myself - theatre, dances, pictures - now I don't go anywhere as I have to keep up a year's mourning. I don't really feel for going out - I don't want to enjoy myself - who would believe that it is the same $\underline{\text { Me now. }}{ }^{21}$

Although all these deaths would have been recorded in Civil Registration and the relevant church/synagogue records, this information alone could not convey any of the emotions, disruption and other context surrounding the event. The diaries both illuminate and humanise the bare fact of an individual death as recorded in official records.

\section{Fertility}

Diaries can provide occasional information on the experience of childbirth, but most usually from the perspective of others in the family rather than from the mother herself. Not only was she usually rather too busy with new motherhood to keep a diary at that time, but also most surviving diaries were written by young unmarried women so that personal experience of childbirth by a diarist was rare. ${ }^{22}$ Elizabeth Lee was the eldest of 12 children born to her mother between 1867 and 1890, and recorded several birth events in her diary. The births appeared to be both routine occurrences only briefly recorded, but also relative surprises to Elizabeth who seemed to have been largely ignorant of her mother's pregnancies until a baby was born. One typical entry reads: 'At 20 minutes to 2 o'clock this afternoon a little Baby boy was born to us. The Doctor did'nt arrive till nearly 3 p.m. The nurse came this morning. It has seemed a queer day. ${ }^{23}$ Likewise John Leeson only briefly recorded in his diary the births of his two children in

${ }^{21}$. Diary of Annie Rudoff, Wednesday May $28^{\text {th }}$ 1923. Bishopsgate Institute Archive, London, GDP/31.

22 . Case notes from midwives may also provide another perspective on childbirth, but from a professional rather than personal perspective.

${ }^{23}$. Diary of Elizabeth Lee, Friday June $28^{\text {th }} 1886$. Pooley et al., Growing up on Merseyside. 
1851 and 1854, although they were clearly events that gave him great pleasure: 'Charlotte my dear wife confined with a son ... his name to be John Rudd Leeson. ${ }^{24}$ The diary also reveals the small changes in John Leeson's life that fatherhood brought. John married relatively late in life and was 47 years old when his first child was born. Although his wife and the nursemaid they employed were responsible for most childcare, he took a real interest in his family and at weekends and on public holidays sometimes recorded walking with them in London parks: 'Good Friday - in afternoon Mrs L, self, baby and Kate [nurse?] and dog had a walk in St James Park - the garden was full of little children who were enjoying themselves playing. ${ }^{25}$

One aspect that the female teenage diaries do record is attitudes to childbirth - both negative and positive. Elizabeth Lee was clearly shocked by the illness of one of her close friends after giving birth, and her diary vividly highlights both the risk to maternal health posed by childbirth in the late-nineteenth century and the impact that this had on Elizabeth's attitude to marriage, even though at 24 she was of an age when marriage might be expected:

Went down to see dear Jessie Lee's tonight. She was confined on the $4^{\text {th }}$ and has got a beautiful boy. She has been at death's door herself; she has'nt [sic] been allowed to eat anything since the baby was born. The Doctor says it would have killed her. She is out of danger now poor darling, and looks very ill and white. ("Catch $\underline{\underline{m e}}$ getting married!') $)^{26}$

Some 30 years later the 18 year old Annie Rudoff recorded a rather more positive attitude towards motherhood after an encounter with a mother and small baby while travelling on a

\footnotetext{
${ }^{24}$. Diary of John Leeson, Friday January $6^{\text {th }} 1854$. Bishopsgate Institute Archive, London, GDP/8.

${ }^{25}$. Diary of John Leeson, Friday April $10^{\text {th }}$ 1852. Bishopsgate Institute Archive, London, GDP/8.

${ }^{26}$. Diary of Elizabeth Lee, Tuesday $14^{\text {th }}$ April 1891. Pooley et al., Growing up on Merseyside.
} 
London tram, though she was equally clear that she was not contemplating marriage any time soon.

Awfully embarrassing today - I was sitting in the tram on the way home - opposite me was a young woman with such a dear baby in her arms - I could have bitten lumps out of it - The kid was coo-ing and gurgling and I just smiled over to it. I couldn't help thinking - "Wouldn't be bad to have one like that " (not now of course not for many years) - I must have had something of what I was thinking in my face for on looking round I caught a young fellow looking at me with such a look on his face - I blushed right down to my toes - and I turned my head away. ${ }^{27}$

Such ambiguous attitudes to marriage and childbirth were probably common to most young women, though they no doubt changed rapidly after marriage and motherhood actually occurred.

\section{Courtship and marriage}

While personal accounts of childbirth are rare, courtship and romance that may eventually lead to marriage were common elements in the diaries, especially those of young women. As seen above with regard to childbirth, John Leeson's diary provides a rather detached factual account of his life - a characteristic probably typical of middle-aged male diary writing - and the account of his marriage is similarly unemotional. John Leeson had been living with his widowed mother in the family home, but after his mother died he married his widowed house keeper (Mrs Rudd) at the age of 46. His diary entry for the wedding reads like an announcement of marriage that might appear in a newspaper, but he gives a much fuller account of the long period of honeymoon holiday they took thereafter:

${ }^{27}$. Diary of Annie Rudoff, Thursday July $24^{\text {th }} 1923$. Bishopsgate Institute Archive, London, GDP/31. 
John Leeson married to Mrs Charlotte Rudd of Norwich - 27th August - Richard, Mrs Crompton, Mr and Mrs Brown, Miss Blackburn, went to church with us, we came home and had Breakfast. Left London at 2 of clock, and went by Railway to Hastings - the day was fine, a slight shower only about 5 of clock. We slept at Mr Smith's King's Head Innthe next morning we took lodgings at No7 Beach Cottages - stayed at Hastings 4weeks then went to Tunbridge Wells for 3 weeks, took lodgings at Mr Baldwin's, Vale Place. Mrs Crompton, Misses Gilbert and Blackburn staying at Rock Lodge a week, where Charlotte was with Mr and Mrs Bull four years since - my knee very unwell there could walk but little on it. $^{28}$

The diary of Verena Black-Hawkins which runs from 1907 to 1939 is also largely factual and provides only scant details of her courtship. She frequently recorded writing to and walking with her future husband (William Somerset Pennefather - referred to in the diary as 'Sommy'), but the formal engagement and marriage are recorded as an official announcement. Occasionally there is a glimpse of the young couple trying to gain time alone before they were married as in an entry for April 1907: 'Went to Kirk. Sommy, Maysie [?] and I walked round the fields before lunch. After lunch went for a walk with Sommy and sat in the den,' but mostly the diary provides only factual accounts of them meeting or writing. Interestingly, shortly after their marriage in 1908 there is a four year gap in the run of diaries, with them resuming in 1913 when Verena had been married five years and had two children. Marriage clearly totally disrupted her diary-writing routine.

Most of the young female diarists recorded frequent liaisons of various sorts with young men, most of which did not lead to marriage, but the process of courting and finding a potential

${ }^{28}$. Diary of John Leeson, entry covering August $27^{\text {th }}$ to October $16^{\text {th }} 1850$. Bishopsgate Institute Archive, London, GDP/8. 
partner loomed large in many diaries. The nature of such meetings changed relatively little over time with walking out (and later motoring) common activities undertaken either as a couple or in the company of other friends. Usually these romantic associations were viewed positively but at times the young female diarists received unwanted attentions. Three brief examples from the 1880s, 1920s and 1950s give a flavour of how romance and courtship was recorded in the diaries.

Went a short walk with Mr. Williams tonight, then had him in the house. Had a good talk with him and we did have such a spoon. Did enjoy myself. It is such a time since we have had such a nice time together. ${ }^{29}$

We were out together all day - in the evening we went for a ride and he took me to some place where there wasn't a soul about. I began to feel nervy. He put his arm round me and started to kiss me, and tried other things. This shill wasn't having any - I told him to quit - and left him..$^{30}$

Coming back Dave and I sat in the back; Dave with his arm round me, singing ... As he remarked at the top of Irton fell, kissing in a Bentley is hugely invigorating. ${ }^{31}$

\section{Migration and mobility}

Residential migration was a relatively uncommon event for most people and only rarely crops up in diary entries. When it does occur it is also often the case that the chaos of moving leads to

\footnotetext{
${ }^{29}$. Diary of Elizabeth Lee, Saturday September $1^{\text {st }} 1888 .$. Pooley et al., Growing up on Merseyside.

${ }^{30}$. Diary of Annie Rudoff, Saturday August $30^{\text {th }}$ 1923. Bishopsgate Institute Archive, London, GDP/31.

${ }^{31}$. Diary of Gillian Caldwell, Friday October $2^{\text {nd }} 1953$. Bishopsgate Institute Archive, London, GDP/1.
} 
very sparse or absent diary entries: selected examples are given below. ${ }^{32}$ In contrast everyday mobility and travel was frequently recorded and diaries can provide a perspective on this aspect of population history that other sources obscure. We have written extensively elsewhere about everyday mobility using diary evidence, so the topic is dealt with only very briefly in this paper. ${ }^{33}$

John Leeson moved home twice in London during the course of his diary. As with other entries his account of the events is very matter-of-fact, but there was clearly a feeling of regret when he moved from the house in which he had lived for 53 years, and the fact that he did not sell the property suggests a lasting attachment. Leeson wrote little about the move itself but appeared to take pride in arranging his new home and was especially pleased to have a garden:

We left No 41 Davies Street after residing there with my parents and wife and children for 53 years for No 19 Upper Phillimore Place Kensington. I let the house to my neighbour Mr John Webb for 21 years from Christmas at $£_{100}$ per year and reduced his rent of No 40 Davies St. ${ }^{34}$

We were busy in arranging the furniture in various rooms. ${ }^{35}$

We had our garden laid out and done up - the first I ever had - planted trees, shrubs and flowers. $^{36}$

\footnotetext{
32. A recent study of migration by one family that, in part, draws on diary evidence is: D. Maund, 'There and Back', Local Population Studies 102 (2019), pp. 82-94.

33. Pooley and Pooley, "'Mrs Harvey came home from Norwich"'; Pooley, 'Cities, spaces and movement'. Pooley, 'Travelling through the city'; Pooley and Pooley, "We're going to move"'.

${ }^{34}$. Diary of John Leeson, October $10^{\text {th }} 1857$. Bishopsgate Institute Archive, London, GDP/8.

${ }^{35}$. Diary of John Leeson, October $17^{\text {th }} 1857$. Bishopsgate Institute Archive, London, GDP/8.

${ }^{36}$. Diary of John Leeson, April $17^{\text {th }} 1858$. Bishopsgate Institute Archive, London, GDP/8.
} 
In contrast Rhona Little (age 18) provided a detailed account of her move from Northern Ireland to London in 1938 to work as a secretary at the Inland Revenue. She had never been to England before and the experience was clearly novel and exciting. A friend (also going to work in London) and both fathers travelled with them. One brief excerpt for part of the journey provides the flavour of her long entry:

The ship rolled up and down after we were out of the Lough. The cabins are very nice if rather small. Daddy and Mr McCurdy have a cabin between them while Kathleen and I have the one next to it. No 11. We saw the dining saloon where we all had a supper of tea and toast and bread and butter. I was not sick at all coming over. We are here at Heysham now. It is nearly 6 o'clock now and it is really Saturday. The rain was dreadful coming in the train and when we went to the boat. ${ }^{37}$

Diaries can also provide evidence of the process of searching for a new home. Ida Berry lived in south Manchester with her widowed mother and two siblings and during the course of the diary sporadically looked for a new home. House hunting was often combined with other activities and was all undertaken within their normal everyday action space. This entry from 1906 is typical: We all went by train to Heaton Mersey and walked to Heaton Moor. We spent the afternoon house hunting and then had our tea at a shop, we came home on the 7.10 train. $^{38}$

If residential moves were rare events, everyday mobility was very common. Many diaries record such movements in detail. Although it is not usually viewed as a key demographic variable, daily mobility can influence other events such as marriage, migration, health and mortality, and is worthy of study in its own right. One other example from the diary of Ida Berry demonstrates the ease with which she moved around Manchester on a variety of different transport modes in

\footnotetext{
${ }^{37}$. Diary of Rhona Little, Friday January $28^{\text {th }} 1938$. Authors' copy.

${ }^{38}$. Diary of Ida Berry, October $27^{\text {th }} 1906$. Bishopsgate Institute Archive, London, GDP/28.
} 
the early twentieth century: 'Glorious afternoon, Mother and I went on the bus to Cheadle and then walked to Cheadle Hulme station and took the train to Wilmslow, we went through the 'Bollin Valley' ... It came on very wet about 7 o'clock so we went by train to Manchester and got home about $9.15 .^{39}$

\section{Conclusions}

Diaries and other forms of life writing can only ever provide a partial picture of the lives of the diarists and the characteristics of the communities in which they lived. Although most local population studies can benefit from the use of diaries where they occur, they must also be combined with other sources to provide a fuller picture of demographic trends, individual lives and local communities. In this short review we have outlined some of the strengths and weaknesses of life writing as a source for local population studies, and have given selective examples of the ways in which diary entries may add detail and context to the key demographic events that are commonly studied in local population histories. Of course, they may be used to shed light on many other aspects of life in the past, including (for instance) dimensions such as household structure, social mobility, inter-generational interaction, reading habits, religion and leisure pursuits. It is likely that some diaries will exist in most local archives and it is well worth searching for examples of life writing when embarking on the study of any community. We all know from our own lives that demographic events such as migration, marriage, childbirth, illness and death have deep resonances that affect the whole family, and sometimes have repercussions for others in the community. Statistical analysis of demographic events can never reveal these human consequences, but diaries may begin to uncover the personal stories that lie behind the bare numbers recorded in Parish and Civil registration.

39 . Diary of Ida Berry, April $27^{\text {th }} 1906$. Bishopsgate Institute Archive, London, GDP/28 